\section{UN/ECE}

- Senior Advisers - Twelfth Session

- Programme of Work 1984-1988

- Outline for National Reviews of Environmental Policies and Strategies in ECE Countries

- Tentative Schedule of Meetings

- Future Activities on International Measures for the Protection of Flora, Fauna and their Habitats (Task

Force Recommendations
1983 South Pacific Forum

Acid Rain: Canada-Europe Ministerial Conference

EC

- European Foundation for Safety at Sea (Motion for a Resolution)

UNEP

- Hazardous Wastes (Ad hoc Group of Experts on the Environmentally Sound Management of Hazardous Wastes)
84

86

\title{
AUTHOR INDEX OF VOLUME 12
}

Bruha, Thomas, 68

Forster, Malcolm J., 64

Ganten, R.H., 5

Koester, Veit, 106
Kromarek, P., 43

Rest, A., 6

Smets, H., 13

Welsch, Hubertus, 72 